\title{
Foreign and native scientists about the ideas and techniques of heuristic education
}

\author{
O. I. Nefedchenko \\ Sumy State Pedagogical University named after A.S. Makarenko, Sumy, Ukraine \\ Corresponding author. E-mail: neoksana@ukr.net
}

Paper received 27.04.18; Accepted for publication 03.05.18.

\section{http://doi.org/10.31174/SEND-PP2018-164VI68-10}

\begin{abstract}
The article highlights sources of ideas and techniques of heuristic education in national and foreign pedagogy. The author investigates various approaches of different researchers according to the essence of heuristic education and ways it's using in secondary and high school. Particular attention is paid to the reasonability of combination traditional and heuristic approaches to educate self-sufficient, professional creative person with great storage of knowledge who is able to analyze information, single out the main point, create new own product and use it in further life.
\end{abstract}

Keywords: heuristic education, independent work, cognitive creative activity, creative product.

It should be noted that the heuristic approaches and ways of activity in the last centuries have found their greatest application in the scientific and inventive activity. However, since the seventeenth century heuristic ideas began to penetrate into the field of pedagogy and education. Socrates' heuristic approaches to the truth's acquisition in educational practice was being developed and improved in the writings of many prominent national and foreign philosophers and educators. Among them J. Komensky, G. Skovoroda, K. Ushynsky, P. Kapterev, V. Sukhomlynsky. All these researchers emphasized on revealing child's natural skills, using creative approaches on different stages of educational process and combining heuristic and traditional methods. Especially V. Vakhterov devoted himself to practical experimental development of using heuristics approaches in private school. The main goal of this work - to find out the formation of ideas and techniques of heuristic education from XVII to XX century. In the article theoretical methods were used, such as analysis, generalization, comparison of different views of scientists educators to a certain problem for the purpose of elucidation of theoretical foundations of research.

The founder of modern didactics Jan Amos Komensky considered you should not knocked already known information collected from various authors into child's head to teach him properly. It is necessary to reveal the child's ability to understand the material, to formulate his own opinion on the topic. The teacher criticized the existing school: “... schools try to teach to look with others 'eyes, to think others' mind ..." [1, c. 68-69]. Following Socrates, J. Komensky called for the identification of objects that are inside and outside of the mind with the help of internal vision. He insisted on making your own discoveries, creating your own thoughts, finding your own way to knowledge, and not studying the ways passed by others. Unfortunately, referring to the modern theory and practice of learning, one can see that the wills of J. Komensky, having a heuristic color, were not implemented in his time. This is due, in our opinion, to various reasons. One of them is the complexity in the conditions of the newly born, yet imperfect classroom system, to overcome the gravity of existing traditional methods of transferring others' ready-made knowledge and to realize learning based on at least some of the fragments of children's creative (heuristic) activity. Under the conditions of the Middle Ages, Socrates, Platon, and later Galileo's breakthrough to heuristic dialogical thinking, heuristic learning and upbringing was blocked by dogmatic monologue with its dominant scheme, "the question of the tutor - the student's response".
The new authoritarian historical climate of that era dictated its rules of thinking and human behavior. Even an outstanding revolutionary in the education of J. Komensky gave a clear preference to the transferring monologue of the teacher, who should listen to the student. Among the outstanding national researchers, whose works laid the foundations for innovation education, it is necessary to mention about the Ukrainian genius Gregory Skovoroda. He laid the first important foundations in the methodology of the new Ukrainian pedagogy and school - their democratic orientation, humanistic principles, creative teaching methods of the growing person, trends and ways of self-development and self-realization. G. Skovoroda opened the main mission-goal of any school - to educate the happy, "for themselves and their brotherhood useful" person [2, p. 324, 327]. Moreover, the way to human happiness is "similar work" both in teaching and in professional work. He put forward the idea of transforming labor from means to life into the first vital need and the highest pleasure. The main pedagogical principle of Skovoroda - the development of man's natural abilities. G. Skovoroda considered the purpose of education is not only learning to find the truth, to know the phenomena of nature, but also inculcating noble feelings, such as friendship, gratitude, and love. The nature of man is characterized not only by his mind but also by "good heart" and "good will". G. Skovoroda gave the world witty and wise tales, skillfully constructed as a Socratic (heuristic) dialogue of actors that accurately, consistently, wittily and reasonably reveals a certain life drama. Therefore, many of them have been used and are now used as models of dialogical and creative forms of education and upbringing. Study of Skovoroda creativity gives grounds to distinguish the main aspects of his heritage, which really influenced and continue to influence the present formation and development of heuristic education. Firstly, it is his main conception that is fundamentally new to philosophy and education, that the goal of every person is to achieve a happy life, and the main factor of this becomes "similar work", which includes the process of learning as a combination of learning others knowledge and experience, and the creation of person's own imagine world with the help of natural individual skills. Secondly, it is worth taking into account the modern scholars of heuristic education G. Skovoroda's idea of the naturalness and the need for real freedom for man. Real freedom should be the acquisition by every tutor of youth, instructor, and teacher. During the great dependence, one cannot speak and assert the truth, successfully investigate, create a new one. 
Outstanding national teacher Kostjantyn Ushynsky is the creator of the fundamental ideas of modern national pedagogy and education. Among them, there are ideas about the essence, meaning and ways of organizing independent students' activities. The outstanding teacher carefully and creatively mastered and redefined the philosophical and pedagogical concepts of ancient Greek scholars (Arkhit, Aristoksen, Socrat, Platon, Aristotel), and works of J. Komensky, Y. Pestalozzi, G. Skovoroda, M. Pirogov and many other famous thinkers. In his writings, K. Ushynsky developed the ideas of the Socrates school about the primacy of voluntary, active and independent mastering of children's knowledge acquisition that the development of human thinking succeeds only in the process of motivated and active independent activity, and the improvement of personality and the development of his abilities - through the deep and constant selfknowledge. K. Ushynsky asserted that "the independence of the student's head is the only firm foundation of any productive teaching" [3, p. 226]. Therefore, the reorganization of the educational process in the modern school K. Ushynsky imagined as organizing a serious and interesting creative independent students' work. The idea of constructing an educational process on the basis of free independent creative (heuristic) students' activity, formulated by K. Ushynsky, for a significant number of teachers even today, seems utopian [4, p. 20].

An important finding of K. Ushynsky was the argumentation that the independent work becomes the source of the child's development only in the case of aiming at free creative search, the work of imagination. K. Ushynsky set this task before didactics as one of the leading. If the memory preserves the material of the original representations, the task of the imagination appears at a higher level - artistic or theoretical. It gives thinking an opportunity for processing material in memory creatively [5, p. 296]. Let us also note such an important moment. K. Ushynsky emphasized that the organization of independent student activity is the most necessary and at the same time, the most difficult mission of the teacher as a creative person and a competent professional. Therefore, he must build his work not on intuition and common sense, but on the scientific basis of didactics and psychology. The teacher believed that three logical moments of knowledge are the objective basis of didactics as a theory of learning, the core of which is the cognitive activity of the student. The first is at the stage of sensory perception. It gives the person's body an impression, which is transformed into a sensation. Sensation leaves a trace in the form of imagination that is perceived and recreated even without subject that gave rise to our impression. The second point knowledge at the stage of the abstract mind (intelligence) operates the concepts worked out on the basis of the abstraction of essential features of feelings and representations, which are generalized in abstract images and expressed in words. The third, higher moment of knowledge, K. Ushynsky considered thinking at the ideological (intellectual) stage. A person who achieves this level of knowledge creates concepts which are characterized by creative orientation $[5, \mathrm{p}$. 629]. The formation of such level of theoretical thinking the main task of independent cognitive activity. Such thinking is formed by the modern heuristic education. Justification of K. Ushynsky's visibility as the necessary means of cognitive and creative students' activity became theoretically new in comparison with the J. Komensky's and J. Pestalozzi's views. The logical thinking that completes the process of knowledge "arises from nothing but only from the right and lasting observations", but "the logic itself is nothing more than a reflection in our mind of the connection of objects and nature phenomena" [6, p. 246-247]. For the first time K. Ushynsky included the child's life experience and the artistic reflection of life in the works of art in the understanding of visual methods. However, K. Ushynsky never overestimated the visual methods, did not consider them as a universal means of organizing the student's activity. This was characteristic of his predecessors; in particular, for Ja. Komensky.

In the process of learning knowledge, according to $\mathrm{K}$. Ushynsky theory, it is necessary to provide students with the opportunity to choose their own cognitive activity. It became fundamental for heuristic didactics. This activity is very productive, and the teacher needs to support it and help students to make the best of their intentions. Thus, the pedagogical heritage of $\mathrm{K}$. Ushynsky contained rather valuable and innovative statements concerning the independent cognitive creative activity of both the teacher and the pupils. Our national pedagogical genius approached the analysis of such activity from the philosophical, psychological, and pedagogical positions, proving the priority of independent acquisition of knowledge, revealing the object and purpose of such activity, revealing the nature of intellectual activity. K. Ushynsky scientifically substantiated some particular ways and means of organizing cognitive and creative independent students' work at the lesson, taking into account the age of education. According to modern scholars of the didactic heritage of Ushynsky, he made a significant step to the development of the doctrine of independent cognitive creative (heuristic) activity. His theory of independent activity closely approached to the disclosure of its main processes - reflection and creativity [4].

Petro Kapterev made the great contribution to the formation of the paradigm of modern education, ideas and technologies of heuristic education. P. Kapterev can be considered the most prominent prerevolutionary theorist of didactic education issues, a researcher of its innovative modernization, in particular the introduction of heuristic learning. Such learning he considered to be the main form of a new educational age, which was formed from the end of the nineteenth and at the beginning of the twentieth century and was associated with significant democratic transformations of society. It is necessary to emphasize that P. Kapterev constructed a new model of the pedagogical process based on a deep and critical analysis of the theories and experience of his prominent predecessors - Socrat, J. Pestalozzi, K. Ushynsky. Kapterev highly evaluated Socrat for discovering a new way of formatting new theoretical knowledge necessary for pupils. Socrat "never transmitted his views dogmatically, but pointing to the disadvantages of conventional thoughts, comparing facts and conclusions known to the audience, he forced his interlocutors to leave false views and make up new concepts about the issue being discussed, more correct ..." [7]. But Kapterev saw in the "Socratic Way", the significant shortcomings. "It is enough to read several dialogues of Platon to see that the center of talks lies in Socrat, that his interlocutors in comparison with him are secondary figures. They only answer the Socrat's questions, agree with his evidence and conclusions, constantly watching their mind in his mind ..." [7]. The scientist is not limited to critical remarks, but offers his own way to improving and developing the educational heuristics of Socrat: "Researching different phenomena, finding out their origin, analyzing their qualities and 
relationships, their synthesis and creating a short formula that combines all the previous individual judgments - everything can be done, of course, under the constant guidance of the teacher by the students themselves, when they are informed of sufficient material and methods of its processing. Then the genetic form of education will be in all its glory and can be called an inventive (heuristic) form". Kapterev revealed the most important, in his opinion, meaning of heuristic learning: "It is impossible to find a means to excite mental activity so much as a heuristic form of learning, because it seems to say to the student: think always as independently as you can. It does not give anything to the student without his own work and effort ... A student who would not want to make mental efforts, tensions, would wish that knowledge were chewed over and given him. Such student cannot study at school where heuristic is the form of study ..." [7].

An outstanding scientist warned his colleagues and teachers of misunderstanding and wrong using of heuristic learning. In his view, heuristic learning methods do not slow down (as some argue) the process of learning, but accelerate its main aspect - the creative and intellectual development of students. However, at the same time, one must adhere to the important conditions: a) firstly study the objects or facts, its properties and relationships, and then give students the opportunity to make generalizations and conclusions on their own; b) actively combine the heuristic study with visibility; c) use guiding questions; d) in no way overload the children with the "amount of information", and carefully focus on the main "information" in order to assimilate them firmly and without excessive repetition; e) carefully prepare for heuristic lessons, use bright and mastery pedagogical stories, while developing both the mind and the deep children's feelings. P. Kapterev called not to be afraid to combine heuristic and dogmatic methods: "The center, the main form of learning is heuristic. How soon is the truth extracted, it is now embodied in the formula and in this form is dogmatically learned" [7, p. 221]. This approach contains side guidance on the need for a reflection procedure and the fixation of a learner's heuristic educational product as a condition of awareness of the educational content created by him.

Another well-known teacher of that time V. Vachterov (1853-1924) dealt with experimental development of active methods of education. The basis of his research work in the Tver private school was the provision that child is not identical to another; each is unique in his own way, "gifted with different abilities, in different combinations and different degrees. Moreover, even the same ability manifests itself at different ages of different children". Therefore, learning should be based on pupils own activities, which can take into account their uniqueness. First the child acts, and then thinks. Practical methods are more effective than verbal. "It is necessary, - considered V. Vachterov - that each student did one or another experience: he drew the scheme of a particular figure, the subject, etc. He made himself a model of wood, paper or clay and told or wrote how one or another experience has been made; one or another observation has been made".

If we continue our excursion into the history of educational heuristics, then we cannot avoid the names of two great teachers and philosophers - J.-J. Russo and L. Tolstoy - the founders of nature-related education and training. J.-J. Russo came out for the development of the child, consistent with his natural qualities, for the natural way of learning and the absence of artificial punishment, which can be replaced by the natural consequences of wrong behaviors. "The only method of education is experience, and the only criterion is freedom", concluded L. Tolstoy on the basis of analysis of the history of the pedagogical development and the results of his school work for peasant children [7, p. 97]. "Everything turns out to be good from the hands of the Creator; everything degenerates in the hands of man". The contradictions between the views of supporters of free education and "state order" continued further. Orientation in Tolstoy's work on children's creativity was criticized by the founder of psychology, as a priority, primary to their age L. Vygotsky: "The undeniable error of this view is the excessive exaggeration and worship of samples of child creativity and the lack of understanding that the spontaneous power of creativity, although capable of creating patterns of greatest tension, nevertheless, is forever forbidden to remain in a narrow circle of the most elementary, primitive and, in essence, poor forms" [8].

Pay attention that the universality of creative activity was emphasized by one of the leaders of humanistic psychology, the American K. Rogers: "I understand the creative process of creating with the help of the action of a new product, which grows on the one hand from the uniqueness of the individual, and on the other - due to the material, events, people and circumstances of life. Our definition does not distinguish the degree of creativity, because it is also very variable estimating definition. Creative character, by our definition, is the action of the child, who invented a new game with his comrades; Einstein, who formulates the theory of relativity; a housewife who invents a new meat sauce, a young author who writes his first novel. We do not try to arrange their actions in any sequence, as more or less creative" [9, p. 412].

In the late XIX and early XX centuries the number of supporters of heuristics is enlarged. They announced the union of lecturing and questioning methods of teaching. It was found that "heuristics really provides the independence of the movement to knowledge, as well as obtaining strong, effective knowledge and skills, but at the same time it requires too much labor and time to obtain these results". [10, p. 175]. As a reaction to the formalism of traditional education at the end of the XIX century there were concepts, methods and techniques of progressivism, which to some extent contain elements of heuristics. Thus, one of the leaders of progressivism, the philosopher and teacher, J. Djui, put forward the position that the child in the process of ontogenetic development in education seems to be in a miniature repeats the way of all mankind, which gradually created, worked out the relevant knowledge [11]. The principle of historicism, put forward by J. Djui, was criticized by the traditionalists and was called erroneous. One of them could not be expected, because the foundations of the proposed by progressives of philosophy were contrary to the traditional science of education and development of the child.

One of the goals of the research station for the national education, headed by Stanislav Shatsky (1878-1934), was the realization of the principle of connection teaching with life and environment. Shatsky considered it necessary to eliminate "children's unemployment", giving students the opportunity of real work, interested and meaningful for them, developing their ability and partnership. However, the implementation of this principle, in particular, the active work of Shatsky on the establishment of children's collective farms, has become the cause of discontent and resistance of 
local peasants. The house of Shatsky's family was burnt down, and the first research station on public education in 1934 was disbanded.

A common approach to the didactics of the 20-30's has been the widespread introduction of brigade-laboratory method of training in schools. This method arose under the influence of the American system of individualized learning, developed by Helen Parkhurst (1924) in Dalton, USA called the Dalton Plan, and was combined with collective forms of learning and project methodology. In this system, students' groups under the guidance of team leaders worked on common tasks from 2 weeks to 1 month. After completing the tasks, the brigades were accountable to the whole class; as a result, they evaluated their work in general. There was no individual labor record, which gave rise to impersonality, irresponsibility and the problem of learning knowledge by backward students.

Abroad, the ideas of natural creative learning were developed in innovative pedagogical systems. Such was, for example, the New School of the French teacher Selesten Frene (1896-1966). His system paid attention to the experience of a child, acquired in the family, school, in the process of communication. S. Frene was convinced that the child creates himself as a personality, and the teacher should help to develop features which are organically inherent to him. Consequently, the center of pedagogical activity he considered the personality of the child, which reveals his potential opportunities, his self-actualization, and not the obtaining his abstract knowledge. An interesting experiment was carried out in France by several "lyceum-pilots", guided by the following principal Frene's teaching methods:1) not to divide educational subjects into main and secondary ones; 2) to master the school program by groups (teams) of lyceum students; 3 ) to use active teaching methods taking into account children's individual inclinations; 4) to teach in close interaction with the environment, cooperation between teachers and students; 5) to transfer examinations into the process of acquiring knowledge.

Their realization takes place in three main directions: program correction, updating forms and methods of training, using technical means. Classes where are no more than 25 students are divided into teams, taking the common interest as a basis in teaching and extracurricular activities. By matching their pedagogical efforts, teachers are teamed up (three in each).The training material is grouped under the socalled synthetic themes. "Lyceum-pilots" are especially concerned about the development of creative imagination among schoolchildren (teachers of literature offer to fantasize on any literary theme, mathematics teachers encourage the imagination of complex geometric figures, physics teachers - to the production of models of mechanisms, etc.). Considerable attention is paid to aesthetic training, one of its' means is regular theatrical performances. Today, up to 10 thousand French teachers use Frene technique. Another such mass informal and at the same time person-oriented direction is not only in France, but also in the world. Frene's contemporary followers emphasize the international significance of his system, believing that "Frene's pedagogy is not specific to French, like the Eiffel Tower" .According to their deep conviction, Frene caused a great interest among the educational community in many countries, as he caught the objective demands that a democratic society must put into school.

The main principle of the didactic system of the Italian teacher and doctor, Maria Montessori (1870-1952): “Help me do it myself". The child is given a choice of the material for working in the class; each pupil can take part in the room for studying. There should not be any foreign objects in the classroom. Particular attention is paid to the emotional atmosphere and the personal contact between teacher and child.

The task of Waldorf pedagogy, developed by the German philosopher and educator Rudolf Steiner (1861-1925), is education of a spiritually free personality. The laws of creativity considered in this system derive from the laws of nature and are expressed in the spiritual experience of a man. Waldorf's teachers see their task as "art of waking up" the natural inclinations hidden in the man.

Considering problems of independent work and creativity in education, one cannot turn to theoretical studies and practical experience of the outstanding Ukrainian teacher Vasil Sukhomlynsky, who attached great importance to various types of students' independent work for the education of their intelligence and creative potential. According to V. Sukhomlynsky's opinion the teacher's wisdom is not to give knowledge in the finished form, freeing children from independent thought. If the teacher tries to facilitate mental work, making sure that the material for the students is the most comprehensible, he "essentially complicates it, as if trampling it, dulls the curious mind" [12, p. 401]. For the developers of the theory and techniques of heuristic education, V. Sukhomlynsky's ideas about the teacher's art were also of great importance to create mental difficulties for students and to guide them elegantly through the selfovercoming of these obstacles. Following V. Sukhomlynsky's logic, we can build a certain chain of consistent approaches and actions of the teacher according to the organization of schoolchildren's independent work, offered by our outstanding teacher:

1. The older students, the greater volume of independent works of a creative nature is. They must perform either in the development of new knowledge, or in the application of already learned.

2. V. Sukhomlinsky emphasizes the necessity of creative nature for senior pupils' independent intellectual work. If intellectual education does not lead to the development of creative mental abilities in the first place, then, in fact, there is no intellectual life of either personality or group [13].

3 . It is necessary to set the goal of independent work not only by the teacher, but also by the students themselves. It is important, "that the goal, which should be achieved in teaching, was put not only by the teacher, but also by the students themselves. If intellectual work is desirable for a student, he strives for the goal not to get a high mark of his work, but mainly to experience the pleasure of discovering the truth"[14].

4. The most important knowledge - empirical, theoretical, applied - the student should not learn and remember, but deduce it by independent analysis of facts, phenomena, solving a wide range of cognitive tasks. "The student does not give ready conclusions, proof the correctness of one or another truth. The teacher gives students the opportunity to put forward a few possible explanations, in the actual fact seek confirmation and refutation of each of the hypotheses put forward" [15].

5. Schoolchildren's independent work is obligatory during all stages of the lesson, especially during the initial study of the material. Only such approach guarantees successful mastery of new knowledge. 
Thus, V. Sukhomlynsky already in the 50-60 years of the last century laid the foundations for a modern paradigm of learning, primarily as a process of creative, dogma-free, restrictive, enslavement of the behavior and activities of the child, and at the same time an intensive, responsible, deeply motivated and successful process. For the conducted research, V. Sukhomlynsky's approaches to building heuristic independent work proved to be particularly valuable as a decisive factor in their intellectual and creative selfrealization of both the teacher and the students. In addition, theoretically and practically substantiated positions of the outstanding teacher concerning the priority of creative activity of those who teach and study in the general structure of the education are considered as important. Without systematic creative work, emotional and intellectual abilities are not developed, there is no desire to learn again and again [16, p. 340].

Heuristics in modern works is interpreted as a methodological science of heuristic activity in teaching and professional work, as special teaching methods of collective or individual problem solving. Thus, with all the diversity of innovative pedagogical ideas of the beginning of the 20th century, many of them are based on the principle of natural creative development of children, which presupposes the availability of goals and techniques for heuristic educational activities.

\section{ЛІТЕРАТУРА}

1. Коменский Я.А. Великая дидактика // Педагогическое наследие / Сост. В.М. Кларин, А.Н. Джуринский. - М.: Педагогика, 1989. - С. 68-69.

2. Сковорода Григорій. Твори у 2 томах. - Київ: АН УРСР, 1961. -Т. 1. - С. 324, 327

3. Ушинский К.Д. Избр. пед. соч. - М.: Педагогика, 1974. - Т. 2.

4. Пидкасистый П.И. Самостоятельная познавательная деятельность школьников в обучении: Теоретикоэкспериментальное исследование. - М.: Педагогика, 1980. $240 \mathrm{c}$.

5. Ушинский К.Д. Собрание сочинений. - М. - Л.: АПН РСФСР в 11 томах, 1948-1950. - Т. 8.

6. Ушинский К.Д. Собрание сочинений. - М. - Л.: АПН РСФСР в 11 томах, 1948-1950. - Т. 7. - С. 246-247.

7. Каптерев П.Ф. Евристическая форма обучения в народной школе // Антология педагогической мысли России второй половины XIX - начала XX в. - М: Педагогика. 1990. C.218-232.

8. Выготский Л. С. Педагогическая психология / Под ред. В. В. Давыдова. - М.: Педагогика-Пресс, 1996. - С. 242.
9. К.Р. Роджерс. К теории творчества. Из книги Взгляд на психотерапию. - М., 1994. - С. 412

10. Куписевич Ч. Основы общей дидактики / Пер. с польск. M., 1986. - C. 175.

11. Д’юї Д. Демократія і освіта. - Львів: Літопис, 2003. - 294с.

12. Сухомлинський В.О. Народження громадянина. - Вибрані твори в п'яти томах. - К.: Рад. школа, 1977. - Т. 3. - С. 283582.

13. Сухомлинський В.О. Проблеми виховання всебічно розвинутої особистості. - Вибрані твори в п'яти томах. - К.: Рад. школа, 1977. - Т. 1. - С. 59-218.

14. Сухомлинський В.О. Сто порад учителеві. - Вибрані твори в п'яти томах. - К.: Рад. школа, 1977. - Т. 2. - С. 419-654.

15. Сухомлинський В.О. Розумова праця і зв'язок школи з життям. - Вибрані твори в п'яти томах. - К.: Рад. школа, 1977. Т. 5. - С. 53-69.

16. Сухомлинський В.О. На трьох китах. - Вибрані твори в п'яти томах. - К.: Рад. школа, 1977.- Т. 5. - С. 339-343.

\section{REFERENCE}

1. Komenskiy Ya.A. Great didactic // Pedagogical heritage / Writer V.M. Rlarin, A.N. Dzhurinskiy. - M.: Pedagogika, 1989. - P. 6869.

2. Skovoroda G. Works in 2 volums. - Kyiv: AN URSR, 1961. -V. 1. - P. 324, 327.

3. Ushinskiy K.D. Selected ped. works. - M.: Pedagogika, 1974. V. 2. - P. 226.

4. Pidkasistyy P.I. Independent cognitive activity of pupils in education: Theoretical experimental research. - M.: Pedagogika, 1980. $-240 \mathrm{p}$.

5. Ushinskiy K.D. Collection of works. - M. - L.: APN RSFSR in 11 volums, 1948-1950. - V. 8. - P. 296.

6. Ushinskiy K.D. Collection of works. - M. - L.: APN RSFSR in 11 volums, 1948-1950. - V. 7.- P. 246-247.

7. Kapterev P.F. Heuristic form of education in public schools // Anthology of pedagogical thought of Russia of the second part XIX - beginning XX c. - M: Pedagogika. 1990. - P. 218-232.

8. Vygotskiy L. S. Pedagogical psychology / Edited V. V. Davydov. - M.: Pedagogika -Press, 1996. - P. 242.

9. K.R. Rodzhers. To the theory of the creation. From the book View to the psychotherapy. - M.: 1994.- P. 412.

10. Kupisevich Ch. The basis of general didactic / Transl. from polish. M., 1986.- P. 175.

11. Diui D. Democracy and education. - Lviv: Litopys, 2003. 294p.

12. Sukhomlynskyi V.O. Birth of the citizen. - Selected works in 5 volums. - K.: Rad. shkola, 1977. - V. 3. - P. 283-582.

13. Sukhomlynskyi V.O. Problems of education of all-round developed personality. - Selected works in five volumes. $-\mathrm{K}$. Rad. shkola, 1977. - T. 1. - P. 59-218.

14. Sukhomlynskyi V.O. One hundred advices for the teacher. Selected works in five volumes. - K.: Rad. shkola, 1977. - T. 2. - P. 419-654.

15. Sukhomlynskyi V.O. Intellectual work and the relationship between school and life. - Selected works in five volumes. - K.: Rad. shkola, 1977. - Vol. 5. - P. 53-69.

16. Sukhomlynskyi V.O. On three whales. - Selected works in 5 volums. - K.: Rad. shkola, 1977. - V.5. - P. 339-343.

\section{Зарубежные и отечественные ученые про идеи и технологии эвристического образования}

\section{О. И. Нефедченко}

Аннотация. В статье освещены источники идей и технологий эвристического образования в отечественной и зарубежной педагогике. Автор исследует подходы разных ученых-педагогов которые касаются сущности эвристического образования и способов его использования в средней и высшей школе. Особое внимание уделено правильности сочетания традиционных и эвристических методов обучения самодостаточного, профессионального творческого человека с большим запасом знаний, способного анализировать информацию, выделять главную идею, создавать новый собственный продукт и использовать его в дальнейшей жизни.

Ключевые слова: эвристическое образование, самостоятельная работа, познавательная творческая деятельность, творческий продукт. 